
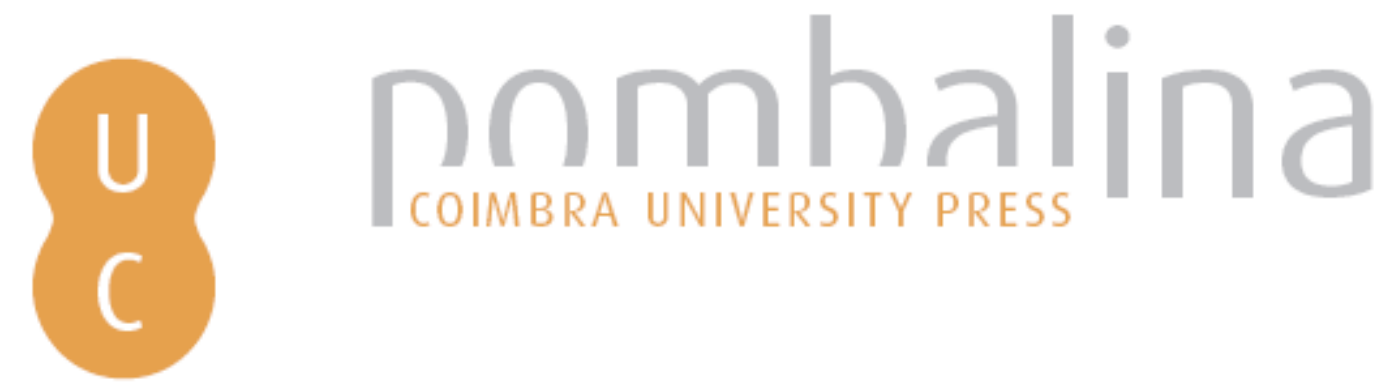

\title{
Transition barriers of accrual accounting in the public sector of developed and developing countries: statistical analyses with special focus on The Netherlands and Egypt
}

\author{
Autor(es): Ouda, Hassan
}

Publicado por: Imprensa da Universidade de Coimbra

URL persistente:

URI:http://hdl.handle.net/10316.2/32175

DOI:

DOI:http://dx.doi.org/10.14195/978-989-26-0422-0_5

Accessed : $\quad$ 26-Apr-2023 12:33:24

A navegação consulta e descarregamento dos títulos inseridos nas Bibliotecas Digitais UC Digitalis, UC Pombalina e UC Impactum, pressupõem a aceitação plena e sem reservas dos Termos e Condições de Uso destas Bibliotecas Digitais, disponíveis em https://digitalis.uc.pt/pt-pt/termos.

Conforme exposto nos referidos Termos e Condições de Uso, o descarregamento de títulos de acesso restrito requer uma licença válida de autorização devendo o utilizador aceder ao(s) documento(s) a partir de um endereço de IP da instituição detentora da supramencionada licença.

Ao utilizador é apenas permitido o descarregamento para uso pessoal, pelo que o emprego do(s) título(s) descarregado(s) para outro fim, designadamente comercial, carece de autorização do respetivo autor ou editor da obra.

Na medida em que todas as obras da UC Digitalis se encontram protegidas pelo Código do Direito de Autor e Direitos Conexos e demais legislação aplicável, toda a cópia, parcial ou total, deste documento, nos casos em que é legalmente admitida, deverá conter ou fazer-se acompanhar por este aviso.

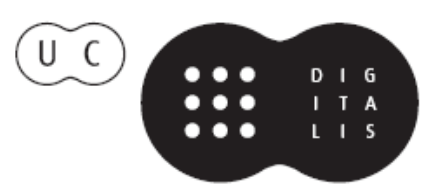




\section{Implementing Reforms in Public Sector Accounting}

Susana Jarge

Editor

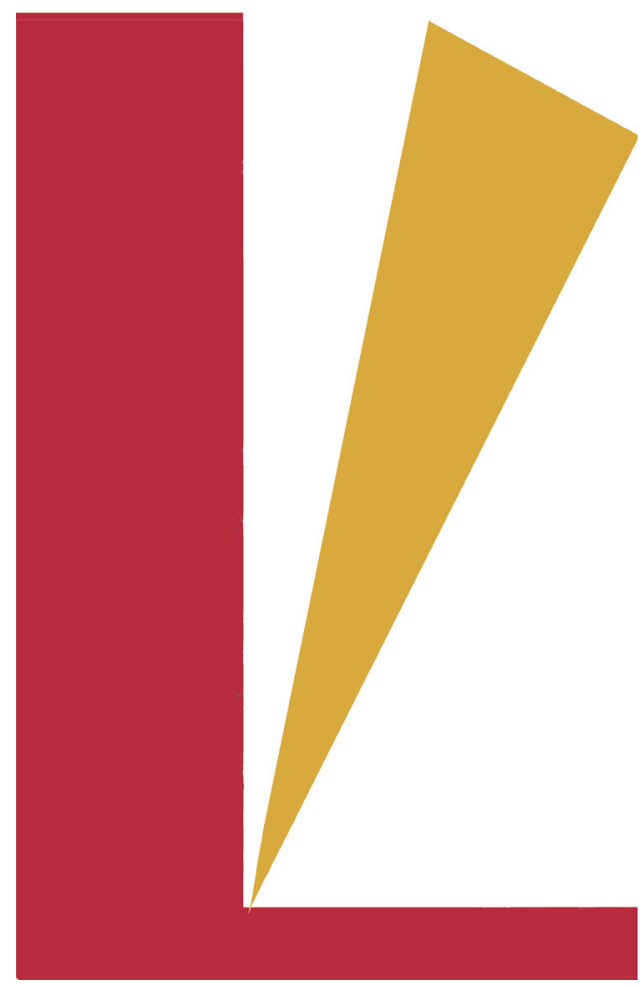


(Página deixada propositadamente em branco) 


\section{Implementing comparative Interational Reforms Governmental in Public Sector Accounting Accounting}

Susana Jorge Editor 
COORDENAÇÃO EDITORIAL

Imprensa da Universidade de Coimbra

Email: imprensauc@ci.uc.pt

URL: http://www.uc.pt/imprensa_uc

CONCEPÇÃO GRÁFICA

António Barros

\section{PAGINAÇÃO}

Simões \& Linhares, Lda.

\section{EXECUÇÃO GRÁFICA}

Simôes \& Linhares, Lda.

ISBN

978-989-8074-39-3

DEPÓSITO LEGAL

$281657 / 08$

\section{OBRA PUBLICADA COM O APOIO DE:}
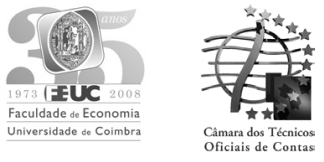

(C) Agosto 2008, IMPRENSA DA UNIVERSIDADE DE COIMBRA 
Hassan Ouda

\section{TRANSITION BARRIERS OF ACCRUAL ACCOUNTING IN THE PUBLIC SECTOR OF DEVELOPED AND DEVELOPING COUNTRIES: STATISTICAL ANALYSES WITH SPECIAL FOCUS ON THE NETHERLANDS AND EGYPT}

\section{Introduction}

While the potential returns from the transition to accrual accounting in the public sector are substantial, so too are the consequences of the transition failure. In reality, the recognition of the transition barriers in an earlier step is substantial as the transition barriers can have a huge impact on the requirements and speed of the transition to accrual accounting. Yet, the identification of the transition barriers gives a clear picture about both volumes of work and financial means necessary for successfully managing the transition process. Therefore, the potential transition barriers need to be identified and tackled before any attempt to adopt the accrual accounting system. This, in turn, can assist in reducing the transition risks and avoiding the transition failure. Accordingly, the transition barriers of accrual accounting in the public sector have been researched and examined by several public sector accounting researchers (Lüder, 1992, Jaruga and Nowak, 1996, Godfrey et al., 2001 and Christensen, 2001). None of these studies has tackled the transition barriers of accrual accounting in the public sector 'in detail', whether theoretically or empirically, and in neither developed nor in developing countries. To fill the void, two studies (Ouda, 2003 and 2005a) have comprehensively researched the transition barriers of accrual in the public sector of both developed (e.g., the Netherlands) and developing (e.g., Egypt) countries. In addition, Lüder (2001) argues that "in the last two decades, government accounting research has emphasized the soft over hard research and the comparative government accounting research so far is almost exclusively non-quantitative research. Statistical analyses would be desirable, for e.g., to find out the significance of the differences of structural and behavioural variables for success or failure of government accounting reform". Furthermore, Lüder (2001) has made the following general remarks on the significance of single independent variables of the Contingency Model:

- The lists of independent variables may be and presumably are incomplete. This is confirmed by several researchers' investigations and their demand for adoption of additional variables; 
- The significance of variables, and thus their influence on the innovation process, may differ and, in fact, does differ;

- The significance of variables may also vary from country to country; and

- It is important to find out if the lists contain variables that have never been observed in any innovation process. These, of course, are candidates for deletion.

In fact, one of the aforementioned studies (Ouda, 2003) has responded to Lüder's invitation (remarks) and performed statistical analyses in order to detect the significance of the differences of the transition barriers between the developed and developing countries.

However, up till now, no study has responded to Lüder's invitation regarding the detection of the significance of the differences of the transition barriers within the developed and developing countries, this in addition to the correlation analyses among the transition barriers within both developed and developing countries. Therefore, the original purpose of this paper is to respond to Lüder's invitation and attempt to fill a gap in the literature by performing the required statistical analyses. While the transition barriers are considered as independent variables, and the transition to accrual accounting is considered as dependent variable, the independent variables themselves within each (country) group are likely not independent (are likely correlated). Therefore, it is necessary to take into account the correlation between the factors being tested due to the fact that they come from the same (country) group. Consequently, the primary purpose of this paper is twofold:

- Detection of the significance of the differences of the factors (transition barriers) that can preclude the transition to accrual accounting within the developed and developing countries (e.g., the Netherlands and Egypt); and

- Examining to what extent the transition barriers are correlated within the developed (e.g., The Netherlands) and developing (e.g., Egypt) countries.

Thereafter the paper is organized in four main sections. The first concerns the theoretical framework and the second describes the research methodology and data collection. Sections 3 and 4 are the most important in the paper. The former analyses the detection of the significance of the transition barriers within The Netherlands and Egypt, first separately, then comparatively. The latter discusses the correlation among the tansition barriers within both countries.

\section{Theoretical development}

As noted earlier, the transition barriers of accrual accounting in the public sector have been researched and examined by several public sector accounting researchers (Lüder, 1992, Jaruga and Nowak, 1996, Godfrey et al., 2001, Christensen, 2001 and Ouda, 2003 and 2005a). Herein, Lüder (1992) mentioned in the Contingency Model, the following four factors as implementation barriers: legal system, staff qualification, size of jurisdiction and organizational characteristics. Since the development of the Contingency Model around 1990, only a few extensions of Lüder's barriers have been set up, leaving the former barriers unchanged (Pallot, 1996). Jaruga and Nowak (1996) have mentioned the following six implementation barriers, the last two of which are originally regarded as Lüder's barriers: system of values, modes of thought, 
content of accountability, system of education, legal system and shape jurisdiction. Furthermore, Godfrey et al. (2001: 282), in their Diffusion-Contingency Model, have stated the same implementation barriers as Jaruga and Nowak's as barriers to change and added one more barrier which is the aid distortion. Moreover, Christensen (2001) has considered the lack of accounting skills in the public sector and inadequate state of asset records as the most confirmed implementation barriers. However, none of these studies has dealt with the transition barriers of accrual accounting in the public sector in detail, whether theoretically or empirically, and in neither developed or in developing countries.

As a step further and complement to the aforementioned studies, two studies (Ouda, 2003 and 2005a) have extensively researched and examined the transition barriers. In these two studies, the transition barriers are broken down into practical transition barriers and conceptual transition barriers. The practical barriers are: legal barriers; cost of designing and installing of a new accounting system; lack of generally accepted government accounting standards; lack of qualified government accounting personnel; resistance to change and the absence of the right incentive system; bureaucratic management culture; lack of internal consistency; lack of external pressure; lack of political commitment; lack of communication about the reform process; lack of information technology capability; the use of traditional (line item) budget and shortage of financial resources. The conceptual barriers are: lack of profit motive; identification and valuation of the existing physical assets; identification of a governmental reporting entity and its boundaries; increase of inflation rates which can create difficulties regarding valuation of governmental assets and liabilities; and the ambiguity around some of the accrual accounting principles and postulations that have given rise to a heavy debate about how they can be applied to the public sector, such as: matching principle, realization principle and going concern. So, in order to have an overview of the transition barriers (whether practical or conceptual) and their criteria of measurement as identified by Ouda's study (2005b), see the following index (Table 1). For the theoretical justification of the transition barriers, we refer to Lüder (1992 and 1994); Pallot (1996); Ball (1994 and 2000); Jaruga and Nowak (1996); Guthrie (1998); Godfrey et al. (2001); Christensen (2001); and Ouda (2003, 2005a, 2005b and 2005c). 
Table 1 - Transition Barriers Index

\begin{tabular}{|c|c|}
\hline Transition Barriers & Measurement criteria \\
\hline \multicolumn{2}{|l|}{ Practical Transition Barriers } \\
\hline - Legal barriers & $\begin{array}{l}\text { Inflexibility of legal system } \\
\text { Lack of legal pressure } \\
\text { Nature of standard setting bodies }\end{array}$ \\
\hline $\begin{array}{l}\text { - Cost of designing and installing of a new } \\
\text { accounting system }\end{array}$ & $\begin{array}{l}\text { Volume of costs required } \\
\text { Lack of technical skills in terms of software and } \\
\text { hardware. }\end{array}$ \\
\hline $\begin{array}{l}\text { - Lack of qualified government accounting } \\
\text { personnel }\end{array}$ & $\begin{array}{l}\text { Education system } \\
\text { Education level } \\
\text { Salary differential } \\
\text { Training system }\end{array}$ \\
\hline $\begin{array}{l}\text { - Lack of accounting standard and practices that } \\
\text { are consistent with the public sector context }\end{array}$ & $\begin{array}{l}\text { IPSAS } \\
\text { ESA } \\
\text { National GAAP } \\
\text { Combination between two of them }\end{array}$ \\
\hline $\begin{array}{l}\text { - Resistance to change and absence of the right } \\
\text { incentive system }\end{array}$ & $\begin{array}{l}\text { Influence of change } \\
\text { Lack of right incentives } \\
\text { Satisfaction with the old system }\end{array}$ \\
\hline - Bureaucratic management culture & $\begin{array}{l}\text { Prevalence of bureaucratic culture } \\
\text { Prevalence of input-system } \\
\text { Absence of output-based system } \\
\text { Permanent tenure system }\end{array}$ \\
\hline - Organizational characteristics & $\begin{array}{l}\text { Decentralization of responsibility for changes in } \\
\text { the accounting regulations } \\
\text { Absence of the internal consistency among and } \\
\text { within the governmental entities }\end{array}$ \\
\hline - Lack of external pressure & $\begin{array}{l}\text { External pressure from executive and legislation } \\
\text { bodies on governmental entities } \\
\text { Demand of improved information by decision- } \\
\text { makers }\end{array}$ \\
\hline - Political factors (lack of political commitment) & $\begin{array}{l}\text { Political culture } \\
\text { Political system } \\
\text { Role of Ministry of Finance }\end{array}$ \\
\hline - Lack of communication about the reform process & Lack of communication strategy and efforts \\
\hline - Lack of information technology capacity & $\begin{array}{l}\text { Degree of computerization of the accounting } \\
\text { system } \\
\text { Required costs }\end{array}$ \\
\hline - The use of traditional budget (line item) & Inconsistency of accounting and budgeting bases \\
\hline - Shortage of financial resources & Financial circumstances of each country \\
\hline \multicolumn{2}{|l|}{ Conceptual Transition Barriers } \\
\hline - Lack of profit motive & $\begin{array}{l}\text { Lack of profit motive in comparison with the } \\
\text { availability of cost information }\end{array}$ \\
\hline $\begin{array}{l}\text { - Identification and valuing of the existing } \\
\text { physical assets }\end{array}$ & $\begin{array}{l}\text { Lack of assets register } \\
\text { Problems associated with valuation method }\end{array}$ \\
\hline - Matching principle & $\begin{array}{l}\text { Absence of direct link between revenues and } \\
\text { associated expenses }\end{array}$ \\
\hline - Realization principle & Diversification of government inflow of resources \\
\hline - Identification of governmental reporting Entity & $\begin{array}{l}\text { Problems associated with identifying the reporting } \\
\text { entity } \\
\text { Approaches used to identify its boundaries }\end{array}$ \\
\hline - Economic factor (inflation) & Inflation rates \\
\hline
\end{tabular}

Source: Ouda (2005b: 220). 
In fact, the segregation of the transition barriers into practical and conceptual transition barriers has raised the following questions:

- Do the transition barriers have the same significance within the developed (the Netherlands) and developing (Egypt) countries?

- Which transition barriers are considered to be more important in comparison with the other barriers within the two countries separately?

- What is the influence of each barrier within each country on the transition process in comparison with the other barriers?

- To what extent are the transition barriers correlated within the developed (the Netherlands) and developing (Egypt) countries?

\section{Research methodology and data collection}

\subsection{Research community (organizational level)}

While it is argued that the Ministry of Finance is most concerned with the government accounting reform, the intention was to encompass different bodies in order to enrich and reinforce the credibility of the empirical research results and to obtain a more comprehensive picture regarding the transition barriers from the standpoint of different bodies in the two countries at the Central Government level. These bodies are displayed in Table 2 .

Table 2 - Research Community

\begin{tabular}{|l|l|}
\hline \multicolumn{1}{|c|}{ In Egypt } & \multicolumn{1}{c|}{ In The Netherlands } \\
\hline - Ministry of Finance & - Ministry of Finance \\
- Central Auditing Organization & - Dutch Court of Audit \\
- Agencies & - Agencies \\
- Different Ministries & - Different Ministries \\
- Academics & - Academics \\
\hline
\end{tabular}

\subsection{Method of data collection}

In gathering the research data, we have used structured interviews based on open questions, structured interviews based on open and closed questions, and self-administered questionnaires (based on open and closed questions). The structured interviews have assisted in getting more insight into practical issues regarding the transition barriers of accrual accounting within the central government of the Netherlands and Egypt. Based on these data, we designed a questionnaire with closed questions in order to get standard answers enabling us to apply a statistical technique. 300 questionnaires (150 for the Netherlands and 150 for Egypt) were prepared and sent to the respondents. The respondents were accountants, financial managers, auditors, chief executives and academics. The data collection process in the two countries has resulted in 119 responses from a total of 300 responses (gross response rate of $39.6 \%$ ), as in Table 3 . 
Table 3 - Results from Data Collection Process

\begin{tabular}{|l|c|c|c|}
\hline & $\begin{array}{c}\text { Absolute } \\
\text { numbers }\end{array}$ & $\begin{array}{c}\text { Percentage related to } \\
\text { target population }\end{array}$ & $\begin{array}{c}\text { Percentage related to } \\
\text { returned surveys }\end{array}$ \\
\hline Target group & 300 & $100 \%$ & $\mathrm{NA}$ \\
\hline Total number of surveys returned & 119 & $39.6 \%$ & $100 \%$ \\
\hline The Netherlands & 54 & $36 \%$ & $45.37 \%$ \\
\hline Egypt & 65 & $43.33 \%$ & $54.63 \%$ \\
\hline
\end{tabular}

\section{Detection of the significance of the differences of the transition barriers}

\subsection{Statistical technique}

The importance of this section stems from the fact that it will be more useful and effective for both developed and developing countries (for e.g., the Netherlands and Egypt) to be aware, from the outset, of the significance of each preclusion factor (transition barrier) and its influence on the transition process in comparison with the other factors. This can assist in reducing or avoiding the risks that are usually embodied in an accounting reform process. Considering that the main purpose of this paper is the detection of the significance of the differences of the transition barriers of accrual accounting within the developed and developing countries (for e.g., the Netherlands and Egypt), it is important to select a statistical technique that can achieve this purpose, and for this we will use the t-test for paired samples. The paired sample t-test is used to assess the significance of difference between means of two variables (factors) in one group (country). Then, mean scores are compared using paired t-test to determine if the impact of each factor on the transition to accrual accounting (within the central government of the Netherlands and Egypt) in comparison with the other factors is significantly different. As such, the decision rules are:

- If (p) value <.05, reject null hypothesis; the difference is probably not due to chance and then the difference is significant.

- If ( $\mathrm{p}$ ) value > .05, accept null hypothesis; the difference is probably due to chance and then the difference is not significant.

Therefore, we are most interested in the means of the two groups and the p-value.

\subsection{Detection of the significance of the differences of the transition barriers (preclusion factors) within The Netherlands and Egypt separately}

Section 1 has identified a number of the transition barriers (whether they are practical or conceptual barriers) that can have a negative impact on the transition to accrual accounting in the public sector. In order to facilitate the statistical analysis, each transition barrier will be given a certain code and some transition barriers have been incorporated into one factor such as the lack of qualified accounting personnel, resistance to change and the absence of the right incentives system are incorporated into one factor, which is the personnel characteristics. Also organizational characteristics 
encompass the absence of the internal consistency among and within the governmental entities; and the decentralization of responsibility for changes in accounting regulations. In addition, the cost of designing and installing a new accounting system and the lack of financial resources have been incorporated into one factor, which is the financial resources. Moreover, the specific accounting issues include the problems associated with the identification and valuation of physical assets, lack of assets registers and problems associated with the identification of the governmental financial reporting entity and determination of its boundaries. So, based on Section 1 (especially the transition barriers index), the following barriers have been identified and will be analyzed in more detail within each country in separate:

- Legal Barriers

- Lack of Accounting Standards

- Bureaucratic Management Culture

- Specific Accounting Issues

- Political Factors

- Communication Barriers

- Accrual Accounting Principles

- Accrual Accounting Postulations

- Personnel Characteristics

- Organizational Characteristics

- Financial Resources

- Economic Factor (inflation)

- Traditional Budget Influence

- Lack of Profit Motive
- LEGBAR

- LAS

- BMC

- SPECAI

- POLFAC

- COMBAR

- AAPRIN

- AAPOST

- PERSCHAR

- ORGCHAR

- FINRES

- ECOFAC

- TBI

- LPM

\subsubsection{The Netherlands}

This section shows the significance and impact of the preclusion factors on the transition process to accrual accounting in the central government of The Netherlands in comparison with each other. Based on the test results, the Table 4 shows the total picture of significance of each preclusion factor in comparison with the other preclusion factors in The Netherlands.

Table 4 - The significance of each factor in comparison with the other factors in The Netherlands.

\begin{tabular}{|c|l|c|c|c|c|c|c|c|c|c|c|c|c|c|c|}
\hline The Netherlands & 1 & 2 & 3 & 4 & 5 & 6 & 7 & 8 & 9 & 10 & 11 & 12 & 13 & 14 \\
\hline 1 & POLFAC & & & & & & & & & & & & & & \\
\hline 2 & SPECAI & & & & & & & & & & & & & & \\
\hline 3 & COMBAR & $\mathrm{X}$ & & & & & & & & & & & & & \\
\hline 4 & AAPRIN & $\mathrm{X}$ & & & & & & & & & & & & & \\
\hline 5 & BMC & & & & & & & & & & & & & & \\
\hline 6 & LEGBAR & $\mathrm{X}$ & $\mathrm{X}$ & & & & & & & & & & & & \\
\hline 7 & LAS & $\mathrm{X}$ & $\mathrm{X}$ & & & & & & & & & & & & \\
\hline 8 & AAPOST & $\mathrm{X}$ & $\mathrm{X}$ & $\mathrm{X}$ & $\mathrm{X}$ & $\mathrm{X}$ & & & & & & & & & \\
\hline 9 & PERSCHAR & $\mathrm{X}$ & $\mathrm{X}$ & $\mathrm{X}$ & $\mathrm{X}$ & $\mathrm{X}$ & & & & & & & & & \\
\hline 10 & ORGCHAR & $\mathrm{X}$ & $\mathrm{X}$ & $\mathrm{X}$ & $\mathrm{X}$ & $\mathrm{X}$ & & & & & & & & & \\
\hline 11 & FINRES & $\mathrm{X}$ & $\mathrm{X}$ & $\mathrm{X}$ & $\mathrm{X}$ & $\mathrm{X}$ & $\mathrm{X}$ & $\mathrm{X}$ & $\mathrm{X}$ & $\mathrm{X}$ & $\mathrm{X}$ & & & & \\
\hline 12 & ECOFAC & $\mathrm{X}$ & $\mathrm{X}$ & $\mathrm{X}$ & $\mathrm{X}$ & $\mathrm{X}$ & $\mathrm{X}$ & $\mathrm{X}$ & $\mathrm{X}$ & $\mathrm{X}$ & $\mathrm{X}$ & & & & \\
\hline 13 & TBI & $\mathrm{X}$ & $\mathrm{X}$ & $\mathrm{X}$ & $\mathrm{X}$ & $\mathrm{X}$ & $\mathrm{X}$ & $\mathrm{X}$ & $\mathrm{X}$ & $\mathrm{X}$ & $\mathrm{X}$ & $\mathrm{X}$ & $\mathrm{X}$ & & \\
\hline 14 & LPM & $\mathrm{X}$ & $\mathrm{X}$ & $\mathrm{X}$ & $\mathrm{X}$ & $\mathrm{X}$ & $\mathrm{X}$ & $\mathrm{X}$ & $\mathrm{X}$ & $\mathrm{X}$ & $\mathrm{X}$ & $\mathrm{X}$ & $\mathrm{X}$ & $\mathrm{X}$ & \\
\hline
\end{tabular}

$\mathrm{X}=$ significant (at $5 \%$ level) 
The results of Table 4 show that there are significant differences between the first 10 factors: political factors, specific accounting issues, communication barriers, accrual accounting principles, bureaucratic management culture, legal barriers, lack of accounting standards, accrual accounting postulations, personnel characteristics, organizational characteristics and the last 4 factors - financial resources, economic factor (inflation), traditional budget influence and lack of profit motive (the observed differences are statistically significant at the $5 \%$ level). Apparently, it seems that the Dutch respondents see that the first 10 factors can significantly affect the transition process to accrual accounting within the Dutch central government in comparison with the last mentioned 4 factors. Based on the test results, the preclusion factors can be categorized into two groups as follows:

Group 1: this group encompasses all the factors that have shown significant differences in comparison with the last four factors. Namely, this group includes the factors that can have more or less a significant impact on the transition to accrual accounting in the central government of the Netherlands. So we might call this group Impact Factors Group.

Group 2: this group comprises all the factors that do not produce significant differences in comparison with the aforementioned ten factors under Group 1. In fact, this group includes the last four factors, which do not seem to have a significant impact on the transition to accrual accounting in the central government of the Netherlands. In connection with Lüder's remarks (2001), these factors are candidates for deletion. Accordingly, we might call this group Deletion Factors Group. Based on the abovementioned segregation, the test results give rise for more analyses for each group separately, as shown below.

\section{Group 1: Impact Factors}

While the test results reveal that there are significant differences between the two groups, each group shows significant differences among the factors that belong to it. The test results show a high level of agreement within the Dutch group that the first five factors show significant differences in comparison with most of the other five factors. Furthermore, the first five factors show a small mean difference among each other. In fact, the mean difference can show the role that these factors can play (as barriers to transition) in comparison with each other. A high degree of preclusion of the transition process can be translated into small mean differences among these factors. So the smaller the mean difference is, the fairly equalled the role that these factors can play as barriers to transition. This also means that these five factors could play a similar role as an impediment to the transition to accrual accounting in the Dutch central government. Consequently, one can conclude that political factors, specific accounting issues, communication barriers, accrual accounting principles and bureaucratic management culture have a profound impact on the transition to accrual accounting in the central government of the Netherlands. Therefore, we might call those five factors Profound Impact Factors. In addition, within the first five factors the test results show that the Dutch respondents gave the political factors and specific accounting issues the highest ranking in comparison with the communication barriers, accrual accounting principles and bureaucratic management culture. Accordingly, it seems that, on the one hand, the Dutch respondents found that the political factors (generally, the lack of political commitment and especially the lack of leadership of the Ministry of Finance) have more impact on the transition to accrual accounting in the Dutch 
public sector in comparison with all the previously stated factors. On the other hand, the test results provide a clear picture of the relationship between the transition to accrual accounting in the central government of the Netherlands and tackling of specific accounting issues in an earlier phase. Perhaps the main reason for the fact that the specific accounting issues rank highly (after the political factors) is the decision of the Dutch Ministry of Finance to use the ESA (European System of Regional and National Accounts 1995) in place of the IPSAS or national GAAP. The ESA has been developed by the international co-operation of economists and national statisticians (not accountants) to present a description of the economy in statistical terms in the form of pattern of accounts and tables which, by logical development and to some extent because of convention, will be understood by economists and administrators specializing in this field throughout the world. Consequently, the ESA is essentially developed for macro-level. Logically, what is developed for the macro-level (national accounting) is not likely to be used at the micro-level (government accounting). Consequently, it can be inferred that the use of ESA has resulted in creating several accounting problems and, hence, has given rise to the great importance of the specific accounting issues. Furthermore, the test results of Table 4 indicate that the legal barriers and lack of accounting standards have less impact on the transition process than the above mentioned five factors, and more impact on the transition process than the last three factors of Group 1 (accrual accounting postulation, personnel characteristics and organizational characteristics). In terms of mean scores, these two factors have almost the same mean scores (legal barriers $M=3.2037$ and lack of accounting standards $M=3.1852$ ). Similarly, the smaller the mean difference is, the fairly equaled the role that the legal barriers and lack of accounting standards can play as barriers to transition. Accordingly, we might call these two factors very important impact factors. Frankly speaking, it seems logic that both legal barriers and lack of accounting standards are to be comprised in one group. In fact, in the absence of the legal provisions and accounting standards that are consistent with the nature of the public sector, there will be quite an ambiguity with respect to the purpose and philosophy of accounting changes as well as the technicalities. In addition, Table 4 reveals that the Dutch respondents agreed that the impact of the accrual accounting postulations, personnel characteristics and organizational characteristics on the transition to accrual within the central government is fairly equivalent, as the results did not produce significant differences among these three factors at the .05 level. Similarly, the results show a small mean difference, which means that the role that can be played by the accrual accounting postulations, personnel characteristics and organizational characteristics, as barriers to transition, is similar. Accordingly, we might call these three factors important impact factors. Consequently, Group 1 can be re-categorized into:

\section{1 - Profound impact factors: \\ - Political factors \\ - Specific accounting issues \\ - Communication barriers \\ - Accrual accounting principles \\ - Bureaucratic management culture}

\section{2 - Very important impact factors: \\ - Legal barriers \\ - Lack of accounting standards}

\section{3 - Important impact factors:}

- Accrual accounting postulation

- Personnel characteristics

- Organizational characteristics 


\section{Group 2: Deletion Factors}

The test results of Table 4 set forth that the financial resources and inflation have almost the same impact on the transition process to accrual accounting in The Netherlands, where no significant difference exists. Whereas the results show that financial resources have a significant impact on the transition process in comparison with traditional budget influence and the lack of profit motive. Based on the mean scores, while there is a significant difference between the financial resources and both traditional budget influence and lack of profit motive, this difference does not mean that the lack of financial resources has a considerable influence on the transition process in The Netherlands. The mean scores of these three factors lie between 1.4815 and 2.5463, which include the areas of disagreement and strong disagreement.

In addition, Table 4 indicates that there is a significant difference between the economic factor (inflation) and the traditional budget influence (TBI) and lack of profit motive (LPM). Similarly, while the impact of the inflation is significantly different from the impact of both TBI and LPM (based on the mean scores of these three factors which lie between 1.4815 and 2.4907), the inflation is not considered a barrier to transition. Consequently, the inflation is considered a candidate for deletion. Similarly, while the test results show a significant difference between the traditional budget influence and the lack of profit motive, based on the mean scores, traditional budget influence is not considered as a barrier to transition.

Based on the above stated test results, the following four factors are candidates for deletion:

- Financial resources

- Traditional budget influence

- Economic factor (inflation)

- Lack of profit motive

\subsubsection{Egypt}

This section analyzes the significance and impact of the previously stated preclusion factors on the transition to accrual accounting in the central government of Egypt.

Based on the test results, the Table 5 summarizes the significance of each preclusion factor in comparison with the other preclusion factors in Egypt.

Table 5 - The significance of each factor in comparison with the other factors in Egypt

\begin{tabular}{|c|c|c|c|c|c|c|c|c|c|c|c|c|c|c|c|}
\hline Egypt & 1 & 2 & 3 & 4 & 5 & 6 & 7 & 8 & 9 & 10 & 11 & 12 & 13 & 14 \\
\hline 1 & LAS & & & & & & & & & & & & & & \\
\hline 2 & BMC & & & & & & & & & & & & & & \\
\hline 3 & LEGBAR & & & & & & & & & & & & & & \\
\hline 4 & POLFAC & & & & & & & & & & & & & & \\
\hline 5 & COMBAR & $\mathrm{X}$ & $\mathrm{X}$ & $\mathrm{X}$ & $\mathrm{X}$ & & & & & & & & & & \\
\hline 6 & SPECAI & $\mathrm{X}$ & $\mathrm{X}$ & $\mathrm{X}$ & $\mathrm{X}$ & & & & & & & & & & \\
\hline 7 & FINRES & $\mathrm{X}$ & $\mathrm{X}$ & $\mathrm{X}$ & $\mathrm{X}$ & & & & & & & & & & \\
\hline 8 & ORGCHAR & $\mathrm{X}$ & $\mathrm{X}$ & $\mathrm{X}$ & $\mathrm{X}$ & & & & & & & & & & \\
\hline 9 & AAPRIN & $\mathrm{X}$ & $\mathrm{X}$ & $\mathrm{X}$ & $\mathrm{X}$ & $\mathrm{X}$ & & & & & & & & & \\
\hline 10 & AAPOST & $\mathrm{X}$ & $\mathrm{X}$ & $\mathrm{X}$ & $\mathrm{X}$ & $\mathrm{X}$ & $\mathrm{X}$ & $\mathrm{X}$ & $\mathrm{X}$ & $\mathrm{X}$ & & & & & \\
\hline 11 & PERSCHAR & $\mathrm{X}$ & $\mathrm{X}$ & $\mathrm{X}$ & $\mathrm{X}$ & $\mathrm{X}$ & $\mathrm{X}$ & $\mathrm{X}$ & $\mathrm{X}$ & $\mathrm{X}$ & & & & & \\
\hline 12 & ECOFAC & $\mathrm{X}$ & $\mathrm{X}$ & $\mathrm{X}$ & $\mathrm{X}$ & $\mathrm{X}$ & $\mathrm{X}$ & $\mathrm{X}$ & $\mathrm{X}$ & $\mathrm{X}$ & & & & & \\
\hline 13 & TBI & $\mathrm{X}$ & $\mathrm{X}$ & $\mathrm{X}$ & $\mathrm{X}$ & $\mathrm{X}$ & $\mathrm{X}$ & $\mathrm{X}$ & $\mathrm{X}$ & $\mathrm{X}$ & $\mathrm{X}$ & & & & \\
\hline 14 & LPM & $\mathrm{X}$ & $\mathrm{X}$ & $\mathrm{X}$ & $\mathrm{X}$ & $\mathrm{X}$ & $\mathrm{X}$ & $\mathrm{X}$ & $\mathrm{X}$ & $\mathrm{X}$ & $\mathrm{X}$ & $\mathrm{X}$ & $\mathrm{X}$ & $\mathrm{X}$ & \\
\hline
\end{tabular}

$\mathrm{X}=$ significant (at $5 \%$ level) 
The test results of Table 5 reveal that the lack of accounting standards, bureaucratic management culture, legal barriers and political factors do have an overwhelming impact on the transition to accrual accounting in the central government of Egypt in comparison with all the other factors. This is because the test results show a substantial and statistically significant difference between these four factors and all the other factors, which in turn implies that the Egyptian respondents have realized that the lack of accounting standards that are consistent with the context of the government sector plays an essential role in precluding the transition to accrual accounting in the central government. Furthermore, prevalence of the traditional bureaucratic model of management and difficulties of changing the bureaucratic culture is one of the main obstacles of the transition to accrual accounting in the central government of Egypt. In addition, the lack of legal pressure on the governing bodies and the governmental entities to move towards the adoption of accrual accounting plays an essential role as a barrier to transition to accrual accounting in the Egyptian central government. Finally, the Egyptian respondents agreed with the Dutch respondents that the lack of political commitment and, in particular, the lack of leadership of the Ministry of Finance is considered a fundamental barrier to the transition to accrual accounting in the central government of both developed and developing countries. Furthermore, the test results have not shown statistically significant differences at the .05 level among the lack of accounting standards, bureaucratic management culture, legal barriers and political factors. The four factors show a very small mean difference among each other and hence they can play an equivalent role as barriers to transition. Consequently, these four factors can form the elements of Group 1, which we might call (similar to The Netherlands case) profound impact factors. Similar to The Netherlands case, the profound impact factors group in Egypt comprises the political factors and bureaucratic management culture. This means that the lack of political commitment and bureaucratic management culture do have a fundamental negative effect on the transition to accrual accounting in both developed and developing countries. In reality, the lack of political and bureaucratic commitment arises because the politicians and bureaucracy are familiar with the old system and the common belief that what worked before will continue to work in the future. It might be because of inadequate knowledge and understanding of the new types of financial reports generated by accrual accounting or because they do not want to be transparent and properly accountable.

In addition, the test results of Table 5 reveal that the communication barriers, specific accounting issues, financial resources, organizational characteristics and the accrual accounting principles do have a significant impact on the transition to accrual accounting in the central government of Egypt in comparison with the rest of the preclusion factors. Similarly, the results indicate that there is no significant difference among the communication barriers, specific accounting issues, financial resources, organizational characteristics and accrual accounting principles (with the exception of the significant difference between the communication barriers and accrual accounting principles, but this was almost 5\% (.049). Based on the mean scores, it seems that the impact of these five factors on the transition process is almost amounted to each other. Based on the test results with respect to these five factors, we can come to the second group which we might call very important impact factors (Group 2). However, comparing The Netherlands case with the Egyptian case regarding the very 
important impact factors can give rise to the following observations: whilst the specific accounting issues are ranked in higher position as a profound impact factor in The Netherlands, these issues do also have a considerable impact on the transition to accrual accounting in the central government of Egypt (as it is ranked as a very important impact factor). This in turn means that there is a consensus between both developed and developing countries on the role which can be played by the specific accounting issues as an impediment. Unlike The Netherlands case, the lack of financial resources is playing a considerable role as a barrier to transition in the developing countries (Egypt) and therefore supports the hypothesis that the lack of financial resources does have a significant impact on the government accounting reform process in the developing countries. It also appears from the practice that the developing countries usually attribute their failure of getting accrual accounting adopted in the public sector to the lack of financial resources.

In addition, the test results have not shown a significant difference between the organizational characteristics and accrual accounting principles, and therefore it suggests that organizational characteristics do have a similar impact to the accrual accounting principles on the implementation process in Egypt. This result is in contrast with the results obtained in The Netherlands case, where the organizational characteristics do have much less impact on the transition process in comparison with the impact of accrual accounting principles, as the accrual accounting principles is recognized as a profound impact factor and organizational characteristics is recognized as important impact factor. Besides the previously stated two groups, the test results of Table 5 show a high level of agreement among the Egyptian respondents that the impact of accrual accounting postulations, personnel characteristics and inflation on the transition to accrual in the central government is fairly similar, as the test results show no significant differences among these three factors. In terms of mean scores, these three factors had mean scores higher than the last two factors: traditional budget influence and lack of profit motive. Accordingly, we might call these three factors important impact factors (Group 3). However, based on the mean scores, the inflation belongs more to Group 4 than Group 3. This means that inflation is not regarded as a barrier to transition, and hence, it is considered a candidate for deletion. Finally, the test results of Table 5 reveal that the use of traditional budget has a significant impact on the transition process in comparison with the lack of profit motive. While there is a significant difference between the traditional budget influence and lack of profit motive, this difference does not mean that the traditional budget influence has a considerable influence on the transition process in Egypt. The mean scores of these two factors lie between 1.8308 and 2.2457 which include the areas of disagreement and strong disagreement. This result is consistent with the results obtained in the Netherlands case. Similarly, based on mean scores, the traditional budget influence is not considered a barrier to transition. Consequently, the traditional budget influence and lack of profit motive (in addition to inflation) can be categorized as deletion factors group. Consequently, the preclusion factors in Egypt can be categorized into four groups as follows: 
Group 1 - Profound impact factors:

- Lack of accounting standards

- Bureaucratic management culture

- Legal barriers

- Political factors

\section{Group 3 - Important impact factors:}

- Accrual accounting postulation

- Personnel characteristics
Group 2 - Very important impact factors:

- Communication barriers

- Specific accounting issues

- Financial resources

- Organizational characteristics

- Accrual accounting principles

Group 4 - Deletion factors:

- Inflation

- Traditional budget influence

- Lack of profit motive

\subsection{Comparative analysis}

Firstly, the categorization of the transition barriers within the two countries has almost conformed the prevailing circumstances and degree of development of each country. For example, the profound impact factors (Group 1) in the Netherlands comprise the factors that reflect the current situation in the Dutch central government. This group encompasses the specific accounting issues and accrual accounting principles. This means that this group sheds light on the current accounting issues (problems) which are required to be overcome from the Dutch respondent's point of view such as: forming and recognition of provisions, forming of reserves, superannuation and pensions (general old-age pension of citizens (AOW)) and preparation of opening balances. This is in addition to the Parliament's fear of accumulation of capital deficit. Furthermore, the Dutch respondents as a developed community see that the lack of communication efforts about the accounting reform process is regarded as a profound transition barrier. Actually, this is in concordance with the nature of the developed communities, that like to be convinced by the feasibility and necessity of any changes whether they are accounting or other. In addition, the Dutch respondents agree with the Egyptian respondents on the importance of the political factors and bureaucratic management culture as real barriers to transition. On the other hand, the profound impact factors Group 1 in Egypt has focused more on the factors that are actually playing a fundamental role in precluding the adoption of accrual accounting and in carrying out any change in the developing countries. This group comprises political factors, legal barriers, bureaucratic management culture and lack of accounting standards. In reality, the dictatorial or semi-dictatorial political systems, conservative bureaucratic culture, fruitless legal systems and inability to produce the accounting standards, which take into account the public sector context, are most of the factors that have impeded the performing of public sector reform in general, and in particular the accounting and budgeting reform in the developing countries. Secondly, Group 2, in Egypt, includes the factors that have been considered as profound factors in the Netherlands whereas it comprises in the Netherlands the factors that have been considered as profound factors in Egypt. In other words, unlike the Netherlands, the specific accounting problems and communication barriers are considered as very important factors in Egypt whereas the legal barriers and lack of 
accounting standards are considered as very important factors in the Netherlands. This means that each country has given the second priority to the factors that are considered to be very important according to the prevailing circumstances in each country. Unlike the Netherlands, the financial resources and organizational characteristics play a very important role in precluding the adoption of accrual accounting in Egypt.

Thirdly, Group 3 has almost comprised the same factors in both countries. This means that both the accrual accounting postulations and personnel characteristics have a similar impact as an impediment to the adoption of accrual accounting in the public sector of both developed and developing countries. Fourthly, the respondents in both countries agreed that the lack of profit motive, traditional budget influence and inflation rates are considered as deletion factors. Namely, these three factors play no or very little role in precluding the transition to accrual accounting in the public sector of both developed and developing countries.

\section{Correlation among the transition barriers (preclusion factors) within both countries}

\subsection{Statistical analysis}

While the transition barriers are considered as independent variables and the transition to accrual accounting is considered as dependent variable, the independent variables themselves within each (country) group are likely not independent (are likely correlated). Therefore, it is necessary to take into account the correlation between the factors being tested due to the fact that they come from the same (country) group. So, in order to determine whether there is a significant correlation between two factors or not, we need to calculate the correlation coefficient ( $\mathrm{r}$ ) and the $\mathrm{p}$ value (probability). Similar to the t-test, the decision rules are:

- If (p) value $<.05$, reject null hypothesis the correlation is probably not due to chance

the correlation is significant.

- If (p) value $>.05$, accept null hypothesis the correlation is probably due to chance the correlation is not significant.

Considering that the focus of this paper is on analyzing the situation in both developed and developing countries, it will be interesting to analyze the correlation between the preclusion factors in The Netherlands and Egypt separately in order to give a full and comparable picture about the correlation among the independent factors in the two countries. Based on the test results, Table 6 summarizes the correlations between each preclusion factor and the other preclusion factors in The Netherlands. 
Table 6 - Correlations between each factor and the other factors in The Netherlands

\begin{tabular}{|c|c|c|c|c|c|c|c|c|c|c|c|c|c|c|c|}
\hline The & Netherlands & 1 & 2 & 3 & 4 & 5 & 6 & 7 & 8 & 9 & 10 & 11 & 12 & 13 & 14 \\
\hline & POLFAC & & & & & & & & & & & & & & \\
\hline 2 & SPECAI & & & & & & & & & & & & & & \\
\hline 3 & COMBAR & $\mathrm{X}$ & & & & & & & & & & & & & \\
\hline 4 & AAPRIN & & X & & & & & & & & & & & & \\
\hline 5 & BMC & X & & & & & & & & & & & & & \\
\hline 6 & LEGBAR & $\mathrm{X}$ & & 2 & & & & & & & & & & & \\
\hline 7 & LAS & & & & & $\mathrm{X}$ & & & & & & & & & \\
\hline 8 & AAPOST & & & & $\underline{X}$ & & & & & & & & & & \\
\hline 9 & PERSCHAR & $\underline{X}$ & Y & 2 & & $\mathrm{X}$ & X & & & & & & & & \\
\hline 10 & ORGCHAR & & & & & & & X & & & & & & & \\
\hline 11 & FINRES & & & & & & & & & & & & & & \\
\hline 12 & ECOFAC & & & & & & & $\mathrm{X}$ & & & $\mathrm{X}$ & & & & \\
\hline 13 & TBI & & & & & & & & & & & & & & \\
\hline 14 & LPM & & & & $\bar{Y}$ & Y & & & & & & & & & \\
\hline
\end{tabular}

$\mathrm{X}=$ significant positive correlation

$\mathrm{Y}=$ significant negative correlation

Similarly, based on the test results, Table 7 summarizes the correlations between each preclusion factor and the other preclusion factors in Egypt.

Table 7 - Correlations between each factor and the other factors in Egypt

\begin{tabular}{|c|c|c|c|c|c|c|c|c|c|c|c|c|c|c|c|}
\hline Egypt & 1 & 2 & 3 & 4 & 5 & 6 & 7 & 8 & 9 & 10 & 11 & 12 & 13 & 14 \\
\hline 1 & LAS & & & & & & & & & & & & & & \\
\hline 2 & BMC & $\mathrm{X}$ & & & & & & & & & & & & & \\
\hline 3 & LEGBAR & $\mathrm{X}$ & & $\mathrm{X}$ & & & & & & & & & & & \\
\hline 4 & POLFAC & & & & & & & & & & & & & & \\
\hline 5 & COMBAR & & & & & $\mathrm{X}$ & & & & & & & & & \\
\hline 6 & SPECAI & & & & & $\mathrm{X}$ & & & & & & & & & \\
\hline 7 & FINRES & & & & & & & & & & & & & & \\
\hline 8 & ORGCHAR & $\mathrm{Y}$ & & & & & $\mathrm{X}$ & & & $\mathrm{X}$ & & & & & \\
\hline 9 & AAPRIN & & & & & $\mathrm{X}$ & $\mathrm{X}$ & $\mathrm{X}$ & $\mathrm{X}$ & & & & & & \\
\hline 10 & AAPOST & & & & & & $\mathrm{X}$ & & & & & & & & \\
\hline 11 & PERSCHAR & & & & & & & & & $\mathrm{Y}$ & & & & & \\
\hline 12 & ECOFAC & $\mathrm{Y}$ & & & $\mathrm{Y}$ & & & & & $\mathrm{Y}$ & & & $\mathrm{X}$ & & \\
\hline 13 & TBI & & & & & & & & & & & & & & \\
\hline 14 & LPM & & & & & & & & & & & & & \\
\hline
\end{tabular}

$\mathrm{X}=$ significant positive correlation

$\mathrm{Y}=$ significant negative correlation

Bear in mind that in both Tables 6 and 7 only the lower left side is shown. This is due to the fact that the correlation is symmetric. In other words, Cor. (X, Y) = Cor. $(\mathrm{Y}, \mathrm{X})$.

As it is clear from the two tables, many factors are correlated with each other within each country separately. However, if we separately interpret and discuss the correlation between each preclusion factor and the other preclusion factors, we shall be confronted with a repetition problem. So in order to avoid this problem, we shall focus the interpretation of the correlation on:

- The factors that demonstrate much correlation with the other factors; and

- The factors that demonstrate particular/higher correlation.

Studying the two tables, it appears that the following preclusion factors (Table 8) have demonstrated much correlation with the other factors. 
Table 8 - Preclusion factors much correlated with the others factors

\begin{tabular}{|l|l|}
\hline In The Netherlands & In Egypt \\
\hline - Political factors & - Political factors \\
- Personnel characteristics & - Lack of accounting standards \\
- Communication barriers & - Communication barriers \\
- Lack of accounting standards & - Specific accounting issues \\
- Lack of profit motive & - Accrual accounting principles \\
& - Personnel characteristics \\
& - Lack of profit motive \\
\hline
\end{tabular}

In addition to the aforementioned factors, the following factors have shown a higher (particular) correlation, above .5:

- In the Netherlands:

- Bureaucratic management culture and lack of profit motive: correlation coefficient $(r)=-.509$

- In Egypt:

- Organizational characteristics and personnel characteristics, where $(r)=.643$

- Financial resources and personnel characteristics, where $(r)=.606$

\subsection{Discussion}

Based on the aforementioned factors, the correlation among the preclusion factors, in addition to the potential reasons behind this correlation, will be discussed as follows.

\subsubsection{Factors that demonstrate much correlation with the other factors in both countries}

- Political factors (lack of political commitment)

The test results of both Tables 6 and 7 indicate that there is a significant positive correlation between the political factors and the legal barriers in the Netherlands and Egypt. Basically, this result suggests that the higher the legal barriers, the more the political factors tend to act as a barrier to transition. In reality, both executive and legislative bodies play a fundamental role in any transition process. More precisely, they complement each other as to the carrying out of the transition process and the enactment of the laws that are required for fulfilling that transition process. It is argued that there is an interrelationship between the political factors and the legal barriers. For instance, the absence of the legal pressure may result in the lack of political commitment. The experience of the earlier reformer countries has confirmed this fact. In New Zealand, during the early to mid-1980s there had been attempts to encourage departments to adopt accrual accounting but a number continued to disregard these attempts. This was a consequence of the lack of legal pressure on the executive bodies to move towards the adoption of accrual accounting. Another example is the inflexibility of legal systems which can make the carrying out of the accounting change, through the executives' bodies, more difficult or at least makes it 
to persist longer. Consequently, the positive correlation between the political factors and legal barriers can be justified. In addition, the correlation coefficient ( $r$ ) is not significantly different in Egypt (.464) from that of The Netherlands (.444), which in turn means that the relationship between the political factors and legal barriers tends to be important in both developing and developed countries.

Another interesting point is the positive correlation between political factors and bureaucratic management culture in The Netherlands. Generally speaking, the Dutch public sector reforms have taken place step by step and they are carried out when and where needed, more in reaction to demands and stimuli from their environment (organic change), and scarcely by means of centrally directed strategic policy steering. In addition, each Minister is responsible for the quality of the public administration and public management of his own area of policy and he or she can deal with the way things are organized and done in his or her ministry. Furthermore, each separate ministry primarily brings public management reform about itself.

Accordingly, "the public management reform is a matter between the Minister and the bureaucracy". Consequently, it is logical that political factors are positively correlated with the bureaucratic management in The Netherlands. So the positive correlation between the political factors and the bureaucratic management culture can be justified where the lack of political commitment gives a signal to the bureaucracy that the government is not serious about the implementation of the accounting reform. Thus, the higher the lack of political commitment, the more the bureaucratic management culture will act as a barrier to transition to accrual accounting. Whilst the test results showed a significant correlation in the Netherlands, they did not produce a significant positive correlation between the political factors and the bureaucratic management in Egypt. One potential explanation is that in the developing countries, it is even more complicated to distinguish the bureaucracy from the politicians. The relationship is mixed and interactive, fluid and integrative, not dichotomous or hierarchical. Thus, the Egyptian respondents eventually consider both of the political factors and bureaucratic management culture as one factor.

In addition, the correlation analysis reveals that there is a significant positive correlation between the political factors and the personnel characteristics in the Netherlands. In fact, this result suggests that the politicians are not so sufficiently different from the bureaucracy. Namely, the lack of the right incentive system, in addition to the lack of dissatisfaction regarding the old system, may also make the politicians resist the change process. Similar to the bureaucracy, the political commitment can be demonstrated by installing an incentive system that motivates them to promote the introduction of accrual accounting and to use the performance information following there from in decision making. This was clear from the New Zealand experience where the public sector reforms were ordered in such a way as to generate early benefits to both bureaucracy and 'Ministers'. Early in the process, bureaucrats received (in exchange for increased accountability for the outputs) the benefits of managing their departments without the need to comply with the extensive detailed procedural requirements. 'Ministers' saw the benefits through their capacity to manage the fiscal situation they faced in preparing the 1991 budget (Warren, 1996).

The most interesting point is the positive correlation between the political factors and communication barriers in the Netherlands. The correlation results suggest that the 
lack of political commitment is associated with the lack of adequate communication efforts. It has generally been proved that politicians do not seriously treat the root cause of their problems until the situation approaches crisis conditions and the need for remedial action becomes urgent and broadly accepted by the unions and population at large (OECD, 1995). Furthermore, public finance is a highly technical and extremely complex field. It is generally difficult to bring non-specialists, such as politicians, to an understanding of the link between the modernization of public services and technical reforms such as the introduction of accrual accounting, budget classification, etc. Therefore, there should be communication endeavoring to teach the politicians to understand the importance of these issues (Chevauchez, 2002). Consequently, the lack of communication efforts, which can make the politicians and populations aware of these issues, may result in a lack of political commitment. Unlike the Netherlands, the test results in Egypt have not shown a significant positive correlation between the political factors and communication barriers. However, the lack of relationship between the political factors and communication barriers can, to some extent, be justified in the developing countries, where most of the communication efforts (such as the media, etc) are subjected to the control of politicians.

Finally, the test results of Table 7 show a significant negative correlation between the political factors and the lack of profit motive in Egypt. This in turn means that the higher the political factors, the less the lack of profit motive acts as a barrier to transition. One possible explanation is that the politicians are much more interested in information about the cost of services provided and the information required for decision-making and discharging the accountability than the profit motive, as the profit motive is not the aim of the public sector which aims at serving the public interest.

- Accrual accounting principles

One of the most logical points is that the test results of Table 6 show a significant positive correlation between the accrual accounting principles and the specific accounting issues in the Netherlands. This in turn means that the Dutch respondents agree that there is a relationship between the emanation of the specific accounting issues and the accrual accounting principles. In reality, the emerging of current specific accounting issues in the Dutch Central Government is associated with the decision of adopting accrual accounting and its principles. For instance, the matching principle means that the revenues, which were earned during the accounting period, should be matched with the associated expenses. The expenses here have to comprise both current and fixed expenses, which have resulted in the inevitability of identification of all current and fixed assets. Thus, the process of identifying the revenues and assets, which expired during the production of those revenues, is fundamental for the matching principle. This causes the problem of identification and valuation of physical assets in the central government, which did not exist under the commitment-cash accounting system. Similarly, realization and recognition principles have given rise to the appearance of different accounting issues. Besides, the most additional accounting problems in the Netherlands such as: forming and recognition of provisions, forming of reserves, superannuation and pensions (general old-age pension of citizens (AOW)) and preparation of opening balances, were also related to the decision of adoption of accrual accounting in the Central Government. 
Another interesting point is that both developed and developing countries agreed on the relationship between accrual accounting principles and postulations. The results of both Tables 6 and 7 show that there is a significant positive correlation between the accrual accounting principles and accrual accounting postulations, which in turn means that the Dutch and Egyptian respondents see that an increase of the role of accrual accounting principles as a barrier to transition is also associated with an increase of the role of accrual accounting postulations. In fact, accrual accounting relies on both principles (e.g., matching, realization, conservatism and consistency principles) and postulations (e.g., accounting entity and going concern). The adoption of accrual accounting principles entails the adoption of the accrual accounting postulations too. The accrual accounting postulations have been seen as a barrier to transition to the same extent as the accrual accounting principles. This was obvious from the problems that have been raised about the reporting entity and determination of its boundaries and the going concern postulation. Accordingly, whoever is inclined either in the developed or in the developing countries to choose the accrual accounting principles as a barrier to transition is also inclined to do the same with the accrual accounting postulations.

Furthermore, the results of both Tables 6 and 7 show a significant negative correlation between the accrual accounting principles and the lack of profit motive. One potential explanation is that the Dutch and Egyptian respondents see that the lack of profit motive is less important in comparison with furnishing reliable information on the cost of government services. This means that the more the impact of accrual accounting principles on the transition process is increased, the more the impact of the lack of profit motive is decreased. The correlation results confirm the results from other statistical test presented in previous sections. In Sections 3.2.1 and 3.2.2 both Dutch and Egyptian respondents have not considered the lack of profit motive an impediment and it is regarded a candidate for deletion.

Unlike The Netherlands, the results of Table 7 indicate that there is a significant negative correlation between the accrual accounting principles and the traditional budget influence in Egypt. This in turn means that an increase of the role of accrual accounting principles as a barrier to transition is accompanied by a decrease of the role of traditional budget influence. Consequently, the correlation analysis confirms the other results obtained in the previous sections (the t-test). Once again, it is confirmed that the traditional budget influence is a candidate for deletion.

- Personnel characteristics

An interesting point is the positive correlation between personnel characteristics and bureaucratic management culture in the Netherlands. This suggests that the intricacy of changing the bureaucratic management culture in the developed countries is more related to resistance to change and the absence of the right incentives system. It is common for resistance to change to come from the bureaucrats who are comfortable with the old system.

Namely, the bureaucrats who are entirely complacent about the status quo will not devote their time and attention to the accounting change and related issues. Furthermore, the lack of an incentive system can also stifle the accounting innovation. In fact, bureaucracy needs to feel that the change will generate benefits for them. For 
example, the New Zealand experience has proved that creating the appropriate incentives has made the bureaucracy assist in carrying out the reform. Scott (1996) stated that departmental heads saw the removal of controls over their inputs as a positive change, and this type of motivation could help to implement the reforms. Financial managers in departments took pride in raising the systems up to the necessary standard, in return for which managers in their departments were given greater freedom to manage. Unlike the Netherlands, the test results of Table 7 have not shown a significant correlation between the bureaucratic management culture and the personnel characteristics in Egypt. This suggests that intricacy of changing of bureaucratic management culture in the developing countries is not related to the absence of the right incentive system but to allegiance to the bureaucratic principles and norms, which generally oppose any endeavor of change. Therefore, the majority of writers who have discussed the government accounting reform, especially in the developing countries, agreed on the notion of transferring key conservative bureaucratic directors during the reform process and recruiting of new reform-minded directors.

In addition, the test results of Table 7 reveal that there is a significant positive correlation between the personnel characteristics and the specific accounting issues in Egypt. The positive correlation means that an increase in personnel characteristics is accompanied by an increase in specific accounting issues. Namely, there is a relationship between the lack of qualified accountants, absence of the right incentive systems and the lack of conviction about the benefits of the new accounting system and emerging of the specific accounting issues. In fact, overcoming the specific accounting issues requires a qualified accountant and incentives systems. Then, the lack of qualified accountants means that the specific accounting issues remain unsolved or even increased. So the greater the lack of qualified accountants and the absence of the right incentives systems, the higher the chance for the specific accounting issues to appear. Surprisingly, the test results in the Netherlands show a significant negative correlation between the personnel characteristics and the specific accounting issues. The negative correlation means that an increase in personnel characteristic is accompanied by a decrease of the specific accounting issues. In fact, the opposite is quite true. This correlation is assumed to be accidental and hence inexplicable (unexplainable).

Another point is the positive correlation between personnel characteristics and communication barriers in both The Netherlands and Egypt. The correlation results suggest that the resistance to change whether in the developed or developing countries is associated with the lack of communication about the reform process. It has been argued that the resistance to change is often emanated as a consequence of the fact that personnel in the field are not informed and consulted. Principles underlying new accounting changes should be first discussed with operations and financial staff to make sure they make sense. Lack of discussion can cause a lot of confusion and impact on moral. Consequently, the resistance to change and the tendency to keep the traditional government accounting system are more related to the lack of adequate communication efforts. In addition, it is the characteristic of the people involved in financial professions to often be reluctant to accept change in the working environment and to want tasks to remain at the same scheduled pace. One of the earlier empirical studies, which has investigated whether or not personality type may have an effect on one's choice of a college major or eventual career, indicated that some business professions 
such as accounting tend to be uncreative and unwilling to encounter "new ideas without being systematically prepared for a new change" and would prefer that everything remain constant (Omundson and Schroeder, 1996). Therefore, taking into consideration the characteristics of accountant and bureaucracy personality, the lack of communication efforts makes the transition process to accrual accounting more difficult in both developed and developing countries.

The results of Table 6 show a significant positive correlation between the personnel characteristics and the legal barriers in The Netherlands. This suggests that the inflexibility of legal systems and the lack of legal pressure on the governmental entities to move towards the change process in the developed countries are often accompanied by the resistance to change and lack of conviction about the benefits of the new system. In addition, this means that whoever is inclined, in The Netherlands, to choose the legal barriers as a barrier to transition, is also inclined to choose the personnel characteristics. However, the results of Table 6 have not shown a significant correlation between the personnel characteristics and the legal barriers in Egypt. This suggests that the developing countries have not yet recognized that the lack of legal pressure and the inflexibility of the legal systems can be accompanied by resistance to change and can make bureaucracy reluctant to change their culture, habits and attitudes.

\section{- Communication barriers}

The test results of Table 7 indicate that there is a significant positive correlation between the communication barriers and the specific accounting issues in Egypt. In reality, the long history of using cash accounting in the public sector has made the adoption of accrual accounting in the public sector to be confronted with a heritage of huge accounting problems, such as forming of provision, identification and valuation of physical assets, lack of assets registers, opening balances, identification of reporting entity and its boundaries, etc.

The lack of communication efforts can result in that these specific accounting issues remain something of a mystery for bureaucracy and the other members who are involved in the government accounting reform. The communication efforts, such as seminars, conferences, case studies, courses, etc, are required to shed light on, debate and discuss the specific accounting issues and clarify what kind of difficulties are involved in these issues, how these difficulties can be tackled and how these issues can be used in the public sector. Accordingly, to what extent the specific accounting issues can remain as a black box is more related to:

- volume of communication efforts (seminars, conferences, case studies, etc);

- the extent to which the specific accounting issues are debated and discussed; and

- the extent to which the outstanding issues concerning the accrual accounting problems can be tackled.

So it is logical that the specific accounting issues are positively correlated with the communication barriers.

In addition, the findings of Table 6 show a significant positive correlation between the communication barriers and the bureaucratic management culture in The Netherlands. The correlation results suggest that the greater the lack of communication efforts, the greater the chance for the bureaucratic management to resist the change. In general, 
bureaucracy can not simply accept the change and give up its behaviour, habits and norms. It is not easy for bureaucracy to move away from input controls, rules and procedures and towards output management and performance targets - the 'accountability' framework. Accordingly, to influence the bureaucratic behaviour via communication requires much targeted contents in messages and careful selection of media. In addition, bureaucracy is similar to some extent to the politicians in the way that they need to be aware of the problem. Furthermore, they do not move towards reform from themselves, rather, there is often a pressure from the politicians on bureaucracy. Accordingly, the lack of the communication efforts may result in the lack of the political pressure and, hence, the lack of bureaucracy support.

In addition, the test results of Table 6 show a significant positive correlation between the communication barriers and the legal barriers. Similar to the politicians and bureaucracy, the legislators need to be aware of the problem and to feel that there is a serious need for enactment of acts that are required for tackling this problem. Close communication with the legislators is essential and it is an ongoing challenge for most of the countries adopting accrual accounting. If the communication efforts do not exist or are insufficient, this may increase the legal barriers. For instance, in order for the governmental entities to feel that there is a legal pressure, this pressure needs to be communicated to them. Otherwise, the legal pressure will remain as ink on paper. Consequently, the lack of legal pressure is often accompanied by the lack of adequate communication efforts. Unlike The Netherlands, the results of Table 7 show that there is no relationship between the legal barriers and communication barriers in Egypt. This result suggests that the developing countries have not yet recognized that the legal barriers are associated with the lack of adequate communication strategy.

Furthermore, the test results of Table 7 show that there is a significant positive correlation between the communication barriers and the financial resources in Egypt. This result suggests that the lack of communication efforts in the developing countries is mostly associated with the lack of financial resources. Communication of the details of accrual accounting with all key stakeholders, in particular the Treasurer, Cabinet, Parliamentarians, Treasury executive, bureaucracy, the public, media and the public interest groups, and dissemination of the objectives of the reform process to all of them, costs money. More precisely, the communication strategy usually consists of: identification of the target audience (stakeholder group), communication of key messages, use of appropriate communication tools, determination of appropriate timing of communications and identification of appropriate communication roles. Carrying out these communication tasks requires sufficient resources. The lack of financial resources will undermine the ability of the developing countries to undertake the aforementioned communication tasks. So it may be inferred that due to the lack of financial means, the developing countries have not paid enough attention to the communication efforts in comparison with the developed countries.

One of the interesting points is the positive correlation between communication barriers and organizational characteristics in Egypt. The positive correlation suggests that the absence of the internal consistency within and among the governmental entities and the production of divergent accounting systems within the public sector are associated with the lack of adequate communication strategy. In fact, achieving a radical government accounting reform requires a consistent framework in which the 
participants in the change process plainly understand their respective roles and are aware of the core of reforms. In addition, overcoming the diversity in the accounting systems within one sector and development of a unified accrual accounting system for the whole central government requires communication efforts on a regular basis. These efforts are necessary in order to raise awareness and insight into the accrual accounting concepts and issues. Thus, the communication barriers may hinder the internal consistency within and among the governmental entities and may make the development of a harmonized/consistent government accounting system within the governmental entities more intricate.

There is also a significant negative correlation between the communication barriers and the lack of profit motive in the Netherlands. This result suggests that the higher the communication barriers, the lower the lack of profit motive as a barrier to transition tends to be. Again, the correlation results confirm the results obtained from the other statistical tests (presented in Sections 3.2.1 and 3.2.2), where the lack of profit motive is considered a candidate for deletion.

\section{- Lack of accounting standards}

The results of Table 6 show a significant positive correlation between the lack of accounting standards and the organizational characteristics in the Netherlands. One possible explanation is that the more the responsibility of changing the accounting regulations and practices is decentralized, the greater the chance of diversification of these regulations and practices, and hence, the greater the chance of lacking unified accounting standards. Basically, the correlation results suggest that the lack of unified accounting standards in the public sector is often associated with the lack of internal consistency among and within the governmental entities and the decentralization of responsibility for changes of accounting practices. Caperchione (1995: 72) points out that the autonomy of governmental entities is an important factor in explaining the variance in their accounting reform. In addition, another writer (Ball, 2000) has argued that the lack of internal consistency among the governmental entities may result in the development of different accounting procedures and practices and consequently in treating the arising problems differently and apart.

In addition, the test results of the two tables show a significant positive correlation between the lack of accounting standards and the bureaucratic management culture in both countries. This result suggests that both developed and developing countries agree that the lack of accounting standards is associated with the prevailing of the bureaucratic management culture in the public sector. However, the correlation coefficient (r) is higher in Egypt (.418) than that of The Netherlands (.296). This in turn means that the relationship between the lack of accounting standards and the bureaucratic management culture tends to be higher in the developing countries. This can further explain to what extent the bureaucratic management culture can impede the development of public sector accounting standards in the developing countries in comparison with the developed countries. This is perhaps due to the fact that bureaucratic management culture in the developing countries (e.g., Egypt) is more conservative and, hence, has more allegiance to the bureaucratic principles. This kind of bureaucratic culture is persistently against any endeavor of reform. In addition, the prevalence of bureaucratic management culture, which does not appreciate the value of improved accounting 
information, may result in preclusion of the efforts exerted to adopt the accounting standards that are consistent with the context of the public sector.

Another interesting point is the positive correlation between political factors and lack of accounting standards in Egypt. This suggests that the lack of accounting standards in the developing countries is associated with the lack of political commitment. Namely, the lack of political commitment in the developing countries could account for the professional and academic bodies' lack of enthusiasm to develop the accounting standards that are consistent with the public sector context and to pursue the implementation of accrual accounting. It also seems that this is a more logical finding in the developing countries where, in absence of the political commitment, nothing can proceed.

Besides, the test results in Egypt show a significant negative correlation between the lack of accounting standards and both accrual accounting postulations and lack of profit motive. This in turn means that the desideration to choose both accrual accounting postulations and lack of profit motive decreases, inasmuch as the desideration to choose the lack of accounting standards (as a barrier to transition) increases. The correlation analysis reveals that the lack of profit motive in the public sector is not a sufficient reason for not developing the public sector accounting standards. This is because the accounting standards in the public sector are not basically directed towards the measurement of net income but rather towards the measurement of efficiency of using the available resources. In addition, the correlation analysis indicates that the respondents do not agree with the assumption that the government is not a going concern. This is in concordance with what has been discussed by IFAC (IPSAS 1, 2004) that there may be circumstances where the usual going concern tests of liquidity and solvency appear unfavourable, but other factors suggest that the governmental entity is nonetheless a going concern.

\subsubsection{Factors that demonstrate particular/higher correlation}

While the previous section (4.2.1) is devoted to discussing and interpreting the correlation of the factors that demonstrate much correlation with the other factors, the primary aim of this section is to focus on the interpretation of correlation of the factors that demonstrate a higher/particular correlation. Bear in mind that if the correlation coefficient ( $\mathrm{r}$ ) is squared, the quotient known as (r2), will indicate approximately the percent of co-variation between variables. Technically, $\mathrm{r} 2$ is called the coefficient of determination. Thus, for example, a correlation coefficient (r) of .50 would yield a coefficient of determination $(\mathrm{r} 2)$ of .25. The fundamental meaning of this numerical fact is that the degree of co-variation is $25 \%$. That is, $25 \%$ of the variance of the $\mathrm{X}$ variable is associated with the variability in the $\mathrm{Y}$ variable.

- Bureaucratic management culture and lack of profit motive: (correlation coefficient $(r)=-.509$ and coefficient of determination $(r 2)=.26)$

The results of Table 6 indicate that there is a significant negative correlation between the bureaucratic management culture and the lack of profit motive in the Netherlands. This means that the more the bureaucratic management culture is perceived as a barrier to transition, the less the role of the lack of profit motive is perceived as an 
impediment. It has been inferred from other studies (Ouda, 2005b) that the lack of profit motive was one of the main reasons for not adopting the accrual accounting system in the central government. However, the t-test (both sections 3.2.1 and 3.2.2) has proved that the lack of profit motive has no significant effect on the transition to accrual accounting. Rather, it is considered a deletion factor. Furthermore, the negative correlation here gives another empirical evidence that the higher the bureaucratic management culture, the lower the lack of profit motive as a barrier to transition tends to be, which in turn means that the impediment of transition to accrual accounting in the central government of the Netherlands is more associated with the bureaucratic culture than the lack of profit motive.

- Organizational characteristics and personnel characteristics: (where $(r)=.643$ and $(r 2)=.41)$

The test results of Table 7 indicate that there is a significant positive correlation between the organizational characteristics and the personnel characteristics in Egypt. One possible explanation of the correlation between the organizational and personnel characteristics is that the diversity of accounting regulation among the governmental entities is likely associated with the lack of qualified accounting personnel who have the accounting capability and are able to communicate with each other to reach unified accounting regulations within the governmental entities. The higher positive correlation between the organizational characteristics and personnel characteristics indicates to what extent the organizational and personnel dimensions are strongly related to each other in case of carrying out any change process. If the attitude of personnel characteristics towards change of accounting system is positive, then the organizational characteristics towards the change process will also be positive. On the other hand, if both dimensions display an opposite attitude, then the barriers to transition tend to be high. In addition, the test results indicate that $41 \%$ of the emergence of the organizational characteristics is related to the personnel characteristics. So the higher the personnel characteristics (namely, lack of right incentive system, resistance to change, lack of qualified accounting personnel and lack of dissatisfaction about the old system), the higher the organizational characteristics (namely the lack of internal consistency among and within the governmental entities and decentralization of responsibility for changes in the accounting regulation) tend to be as a barrier to transition. Consequently, both personnel and organizational characteristics should be treated and overcome on a parallel basis if the transition process needs to be successful.

- Financial resources and personnel characteristics: (where $(r)=.606$ and $(r 2)=.37)$

The test results of Table 7 show that there is a significant positive correlation between the financial resources and the personnel characteristics in Egypt. Similarly, the higher positive correlation between the personnel characteristics and the financial resources shows to what extent the existence of personnel characteristics in Egypt can be related to the lack of financial resources. Basically, $37 \%$ of the emergence of the personnel characteristics is associated with the lack of financial resources. In fact, the lack of qualified accounting personnel, lack of right incentive system and resistance to change require sufficient financial means to be overcome. In the 
absence of financial resources, these problems will remain unsolved, and this in turn will preclude the transition to accrual accounting. Accordingly, the existence of the personnel characteristics as transition barriers is more associated with the lack of financial resources in the developing countries (Egypt).

\section{Conclusion}

In the course of Section 4, the following results have been reached.

Firstly, the most positively correlated factors with each other and with the other factors in the Netherlands are the personnel characteristics, political factors, communication barriers, legal barriers and bureaucratic management culture. In addition to the results obtained from the t-test, the correlation analyses proved that the aforementioned factors have a significant impact on the transition to accrual accounting in the Dutch central government. Furthermore, Section 4.2.2 indicated that the impediment of transition to accrual accounting in the Dutch Central Government could be more related to the bureaucratic management culture than to the lack of profit motive, where the correlation results indicate that there is a significant negative correlation $(r=-.509)$ between the bureaucratic management culture and the lack of profit motive. Secondly, the most positively correlated factors with each other and with the other factors in Egypt are the accrual accounting principles, lack of accounting standards, political factors, financial resources, organizational characteristics, specific accounting issues and personnel characteristics. Similar to the Netherlands, the above stated factors have a significant impact on the transition to accrual accounting in the Egyptian central government. In addition, Section 4.2 .2 has proved that $41 \%$ of the variance of the organizational characteristics is associated with variability in the personnel characteristics and $37 \%$ of the variance of the personnel characteristics is associated with variability of the lack of financial resources.

Thirdly, it seems that the lack of profit motive is the most negatively correlated factor with a great part of the other factors in both countries. This factor is negatively correlated with the communication barriers, accrual accounting principles and bureaucratic management culture in the Netherlands and it is negatively correlated with the lack of accounting standards, political factors and accrual accounting principles in Egypt. This means that the higher the role of these factors as barriers to transition, the lower the lack of profit motive tends to be a barrier to transition. The correlation results therefore confirm the results obtained from the t-test, where the lack of profit motive is considered a candidate for deletion.

\section{References}

Ball, I. (1994), Initiatives in Public Sector Management and Financial Management: The New Zealand Experience in Anderson, A., Financieel beheer,verslaggeving en prestatiemeting bij de Rijksoverheid, Symposium verslag, 2 November, Circustheater Schevenongen, 10127/1.

Ball, I., et al. (2000), Reforming Financial Management in the Public Sector: Lessons U.S. Oofficials can Learn from New Zealand, http://www.rppi.org/privatization/ps258.html. 
Caperchione, E. (1995), Governmental Accounting Changes and Italian Public Administration renewal in the Nineties, in Montesinos, V. and Vela, J. M., (eds), International Research in Public Sector Accounting, Reporting and Auditing, Instituto Valenciano de Investigaciones Económicas, S.A, 61-80.

Chevauchez, B., (2002), Government budgeting and accounting reforms in France, in Models of Public Budgeting and Accounting Reform, OECD Journal on Budgeting Volume 2, Supplement 1, 285-304.

Christensen, M., (2001), Public Sector Accrual Accounting: Who Made the Emperor's Clothes?, Manuscript submitted to APIRA.

Godfrey, A. D., Devlin, P. J. and Merrouche, M. C. (2001), A Diffusion-Contingency Model for Government Accounting Innovations, in Bac, A. (ed.), International Comparative Issues in Government Accounting, Boston et al: Kluwer, 279-296.

Guthrie, J. (1998), Application Accrual Accounting in the Australian Public Sector - Rhetoric or Reality?, Financial Accountability and Management, Vol.14, No.1, 1-19.

IFAC (IPSAS 1) (2004), Presentation of Financial Statements.

Jaruga, A. and Nowak, W. (1996), Towards a general model of public sector accounting innovations, Research in Governmental and Non-profit Accounting, 21-31.

Lüder, K. (1992), Contingency Model of Government Accounting Innovations, Research in Government and Nonprofit Accounting, Vol. 7, 99-127.

Lüder, K. (1994), The Contingency Model Reconsidered: Experience from Italy, Japan and Spain, in Buschor, E. and Schedler, K. (eds.), Perspectives in Performance Measurement, Berne Haupt, 1-15.

Lüder, K. (2001), Research in Comparative Governmental Accounting over the Last Decade- Achievements and Problems, Working Paper (CIGAR 8 Conference Valencia, 14th-15th June).

OECD, (1995), Budgeting for Results, Perspectives on Public Expenditure Management, (Paris: OECD).

Omundson, J. S. and Schroeder, R. (1996), Type A Personality, Job Satisfaction, and Turnover Intention Among Certified Public Accounts, Hispanic Journal of Behavioral Sciences, 18, 39-51.

Ouda, H. (2003), Implementation Barriers of Accrual Accounting in the Public Sector of Developed and Developing Countries: An Empirical Investigation, Paper presented at the 9th CIGAR Conference, Bodo University, Bodo, Norway, 13-14 June 2003.

Ouda, H., (2005a), Practical and Conceptual Transition Problems of Accrual Accounting in the Public Sector, ICGFM - Public Fund Digest, Vol. 5, No. 2, Aug.

Ouda, H., (2005b), Transition to Accrual Accounting in the Public Sector of Developed and Developing Countries: Problems and Requirements, with Special Focus on the Netherlands and Egypt, Universal Press, Veenendaal, The Netherlands, 405.

Ouda, H. (2005c), Additional Transition Problems of Accrual Accounting in the Public Sector of Developing Countries, ICGFM - Public Fund Digest, Vol. 5, No.1, 92-98.

Pallot, J. and Ball, I. (1996), Resource accounting and budgeting: The New Zealand Experience, Public Administration, Autumn.

Schick, A. (1999), Opportunity, Strategy, and Tactics in Reforming Public Management, OECD, Symposium, Paris 14-15 September.

Scott, G. (1996), Government Reform in New Zealand, International Monetary Fund, Washington, October.

Warren, K. (1996), Implementation accrual accounting in government: The New Zealand Experience, IFAC, Occasional paper 1, December. 


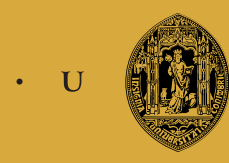

C - 